\title{
Forging Freedom from Fear
}

\author{
Jaap A. Walkate
}

\author{
Chairman, Board of Trustees, United Nations \\ Voluntary Fund for Victims of Torture, \\ Ambassador of the Kingdom of the \\ Netherlands \\ Originally presented as the Brock Chisholm \\ Memorial Lecture, Medical Society of the \\ World Health Organization, 24 May, 1996 \\ Correspondence: \\ Jaap A. Walkate \\ Ministry of Foreign Affairs \\ P. O. Box 20061 \\ 2500 ED The Hague \\ The Netherlands
}

\section{Abbreviations: \\ UN $=$ United Nations \\ $\mathrm{WHO}=$ World Health Organization}

Date Received: 25 September, 1997

Accepted: 12 December, 1997

\section{Introduction}

Before I expose my subject, I would like to pay tribute to the memory of Dr. Brock Chisholm, first Director-General of the World Health Organization, whose memory inspired the establishment of this lecture. Those who did so obviously hoped to create a chain of inspiration leading from the root of the Organization into the future, and thus, build a monument to this great man.

The World Health Organization (WHO) is an organization characterized by the meeting of several disciplines: medicine, of course, but also social science, psychology, law, political science, diplomacy, and ethics, just to mention the most important ones. It is especially the combination medicine, law, and ethics that interests me, because it is at the basis of much of the human rights work I have done in the past. The creation of a sound society requires the participation of sound people, both mentally and physically. A society dominated by force and violence produces fear in its participants, and fear is crippling, paralyzing, and debilitating in its effects - a negation of health as conceived by WHO. For, in its far-sighted spirit under the guidance of Dr. Brock Chisholm, this World Health Organization, from its very inception, established a fundamental concept of health that is very germane to the subject that I wish to develop. The WHO Constitution defines "health" as "a state of complete physical, mental, and social well-being, and not merely the absence of disease or infirmity". The absence not only of physical, but also of mental and social well-being, therefore, constitutes a lack of health, an ill-being that is so characteristic of violence, fear, persecution, and loss of human dignity.

Lawyers and physicians have the common duty to maintain and wherever necessary, to restore the physical and mental sanity of the society to which they belong. They, therefore, must guard against any violation of fundamental rules of law and ethics by the authorities of the State which may damage its citizens, both physically and mentally.

\section{The Omnipotent State}

It is the State that exercises too much power or undue power vis-à-vis its citizens of which we must beware. In a society in which the use of force has been monopolized; at least by rule of law, there always is the danger that this monopoly will be abused so that citizens become victims of domination, intimidation, and violation of rules to guarantee the privacy, dignity, and integrity of the individual person. This is all the more so in a situation in which the individual finds him/herself in the hands of the authorities of the state, either de jure, by application of the rule of law, such as in any criminal procedure, or de facto, by the abuse of the rule of law, such as is bound to happen under dictatorship and disregard for the rules of a democratic society. In these situations, fear may be instilled, damage may be done, illness may be caused, irreparable invalidity, either mental or physical, may be produced or, certainly not by way of exception, death may occur. We cannot be too precise nor take enough care in the maintaining of the rule of law, in the administration of justice, in the execution of lawful punishment, in the safeguarding of the individual's vulnerable position, and guaranteeing of the individual's human rights, including his right to "the enjoyment of the highest attainable standard of physical and mental health", in short, in protecting the human integrity of each individual.

Freedom from Fear and from Infringement of One's Integrity I submit that lawyers and physicians have similar duties in playing their role 
in society: to uphold and restore the legal, mental, and physical integrity and dignity of their (potential) clients/patients wherever these are confronted with abuse by the State and seek compensation for any damages or losses sustained.

A lot will be gained already when a society free from fear can be created. Freedom from fear was one of the four freedoms enumerated by President Roosevelt in his State of the Union Address of January 1941, when he said that no nation can remain safe or free unless protected by a united world order founded on four essential freedoms: 1) freedom of speech; 2) freedom of worship; 3) freedom from want; and 4) freedom from fear: fear to lose one's freedom, one's dignity, one's health, or one's life. The four freedoms did not include the freedom from infringement of one's integrity; neither did any of the international documents that followed explicitly mention that freedom. Nevertheless, it is this freedom that permeates all international rules relating to the protection of human rights in the framework of the United Nations: the Charter that was at the root of the United Nations (1945), the UN Declaration of Human Rights (1948), the UN Covenant on Civil and Political Rights (1966), the European Convention (1950), the American Convention on Human Rights (1969), and so many other specific conventions and regulations of which I should at least mention the UN Convention against Torture (1984). They speak of the "inherent right to life", "the right to security of person", "the right not to be subjected to torture or to cruel, inhuman or degrading treatment or punishment", "the right to be treated with humanity and with respect for the inherent dignity of the human person".

They all are based on the notion that the State refrain from any action that might cause harm to the body, the mind, or the soul of the individuals under its jurisdiction which cannot reasonably be considered necessary for his detention or imprisonment on legal grounds. In this context, I would like to discuss a few topics related to the situation in which the State, either lawfully or unlawfully, has arrested a person and or detained him, to begin with the crucial period between arrest and detention, crucial both for law enforcement officers and alleged perpetrators of crimes.

\section{The Period Between Arrest and Detention}

It is a widely known fact, established by many United Nations reports, that most cruel, inhuman, or degrading treatment occurs during the first hours and days of the detention of an arrested person. During that period, violation of human rights such as incommunicado detention, disappearances, extra-legal executions, and organized torture tend to occur. Enforced or involuntary disappearances violate practically all fundamental rights, such as the liberty and security of person, the right not to be subjected to torture, the right to recognition as a person before the law, the right to legal remedies, such as habeas corpus, and, as the case may be, the right to life. The same reports have established repeatedly that it takes more than legislation to prohibit and sanction these practices. Not only should the rules of the law be published and taught, but it also must be made clear that the responsible authorities will, under no circumstances, condone any violations of these rules.

\section{Torture Practices Must Be Publicly Rejected as Illegal}

It is of the utmost importance that there never should be any doubt in the mind of those who are responsible for detainees or arrested persons that torture or other cruel, inhuman, or degrading treatment is prohibited by (international) law, and that it is not approved by the government or by law enforcement policy. I am absolutely convinced that there is nothing so important in the struggle for a humanitarian law enforcement system without the use of undue force or violence as is an unconditional, official denunciation of such illegal practices.

Such a denunciation not only should be made by the politically responsible authorities but also, and even more so, by all those in the law enforcement hierarchy. Thus, it never can be argued that perpetrators of illegal detention practices could have taken them as a lawful instrument of government policy. A simple text like "THE GOVERNMENT DOES NOT TOLERATE TORTURE OR CRUEL, INHUMAN, OR DEGRADING TREATMENT; PEREETRATORS WILL BE PROSECUTED" should be displayed in all police offices and places of detention. In those cases in which law enforcement personnel cannot read, the denunciation also should be made in the form of an oral instruction. I offer this sug gestion because scientific research has established that torture and other mal-treatment's are no ordinary crimes, but "crimes of obedience". A crime of obedience has been defined as a crime that takes place not in opposition to the authorities, but under explicit instructions of the authorities. ${ }^{2}$ The fact that crimes of obedience take place within a hierarchical structure, makes it especially difficult to pinpoint responsibility for them. This, however, does not take away from each and everyone's responsibility under the law within the penitentiary system. The advantage of a clear and unambiguous denunciation as described above is that no one will have the excuse of saying: "I did not know" or "the circumstances were so pressing that they seemed to allow for torture". In this respect, it should be realized that the relevant international rules regarding torture do not allow for suspension of the prohibition in times of public emergency or of war. ${ }^{3}$ The official proclamation of a state of emergency or state of siege, therefore, never relieves a government of the obligation to enforce the relevant provisions against torture and ill-treatment.

\section{Corporal Punishment is Unlawful Sanction}

After arrest, the detainee is held in the penitentiary system either in a preventive detention center where he/she may await further proceedings or in a prison where he/she will be submitted to the lawful sanctions to which he may have been sentenced. As "lawful sanctions", I do not consider those sanctions that have an irreversible 
effect on life, physical health, or human integrity of the individual concerned. In any event, I cannot consider them as "lawful" under international law. I am referring, of course, to corporal punishment or treatment, as they still exist in penal and penitentiary systems of member countries of the WHO. In legal terms, one should qualify corporal punishment as "legalized" torture or at best as legalized cruel or degrading treatment or punishment. In this context, I am referring to lashes with whip, rod, or reed, amputation of limbs (sometimes even two at a time: right hand and left foot), blinding, or stoning. This last form of punishment also may be considered as a form of capital punishment. Due to the limited space I have at my disposal, I will not argue the obvious case for the abolition of the death penalty which should be considered a form of corporal punishment in extremis and a fortiori unacceptable. As regards the unlawfulness of corporal punishment, my view is supported by a leading decision by the Human Rights Committee, established under the UN Covenant of Civil and Political Rights, to the effect that the prohibition of torture extends to corporal punishment. ${ }^{4}$

\section{Involvement of Medical Personnel}

The application of measures, such as torture or corporal punishment, often implies the cooperation of medical personnel, physicians, or paramedical staff. To begin with, torture pur sang, I can inform you, however incredible it may sound, that according to reliable, reports in many cases, medical personnel have been involved: sometimes by devising methods of torture that do not leave visible scars on the victim, sometimes by preventing torturers to go too far and to lose a valuable detainee who still should disclose more information, sometimes by reviving victims to prepare them for another round of beatings.

The false certification of mental illness is yet another unacceptable act. This conduct has been declared not only as illegal and punishable, but also as a "gross contravention of medical ethics" by the UN General Assembly in 1982 through the adoption of its Principles of Medical Ethics relevant to the Role of Health Personnel, particularly Physicians, in the Protection of Prisoners and Detainees against Torture and other Cruel, Inhuman or Degrading Treatment or Punishment. ${ }^{5}$

It is interesting to note that the same body of Principles declares inadmissible and a contravention of medical ethics, the certification or participation in the certification of the fitness of prisoners or detainees for any form of treatment or punishment that may adversely affect their physical or mental health, nor to participate in any way in the infliction of any such treatment or punishment. This is a clear reference to the participation of medical doctors in the application of corporal punishment, be it beatings or amputations, a participation that should be avoided under any circumstance, except in the cases where the physician is called upon to treat the wounds. I call on Ministers of Health and other high officials for the World Health Assembly, to be aware and ever vigilant of these unacceptable breaches of medical ethics and to prevent such human degradation.

\section{The Dilemma of the Certifying Physician}

The practice of corporal punishment in some countries may place doctors who refuse to cooperate in a difficult situation. Dutch medical doctors who were employed by the local government agency for health and on secondment in the framework of development aid and who did not agree with the practice of corporal punishment, refused to cooperate and certify prisoners for fitness to undergo corporal punishment. Without such certification, the punishment may not be implemented and the prisoner will be condemned to undergo a prison sentence. It has happened that the prisoner begged the prison doctor to give permission for the beatings because the alternative would be imprisonment in a filthy, stinking prison cell and, worse, would deprive him of his freedom and, thus, from the possibility to work and earn some money to maintain his family. Here, the doctor found himself in a terrible dilemma: heed the request of the prisoner or abide by his code of medical ethics? The doctor gave preference to his medical duty and did not certify the prisoner; Result. dismissal by the local health authority who rather appointed to the job a local doctor raised with the local custom of corporal punishment. By certifying the prisoner, he chose to violate the code of medical ethics. It might be of interest to know the follow up to this - not unique - incident. The Ministry of Foreign Affairs of the Netherlands, confronted with requests to morally support expatriate Dutch physicians in foreign government service refusing fitness-certification, decided in the mid 1980 s to provide such doctors with an official statement to the effect that corporal punishment, in the opinion of the Netherlands Government, is not in accordance with international human rights instruments and that therefore, the involvement of health personnel in fitness-certification should be avoided. A triumph for the freedom from infringement of personal integrity!

\section{The Law Enforcement System as a Mirror}

The effect of the law enforcement system, and in particular, the penal and penitentiary system, on society atlarge should not be underestimated. That system and society at large may be seen as each other's mirror images. And more than this, they will influence each other mutually. A violent, unscrupulous, and unforgiving law enforcement system will produce (more) violence and (even more) unforgiveness in society and vice versa. Therefore, a system based on the individual's freedom from infringement of his personal integrity, administered under the guidance of independent judges and in strict adherence to internationally agreed human rights may be expected to yield positive results and fulfill an efficient role in creating a society with less violence, crime, and aggression. It would seem to me proof of sound and solid penal and penitentiary policy if a society, at the same time, would reject any form of corporal or capital treatment or punishment. For a penal system with capital and/or corporal punishment or treatment 
will have as a consequence that society accepts a judicial system which authorizes the killing, mutilation, violation, humiliation, and/or degradation of members of that society. In essence, such a society would seem to be self-destructive.

\section{The Fight Against Torture}

Long gone are the days of the middle ages and the renaissance when corporal or capital punishment was meted out for relatively minor crimes such as theft or robbery. They also were the days when the conviction of the accused was based on evidence obtained from the accused by torture that, in many cases, inevitably led to convictions without the perpetration of a crime, and thus, detention or execution of innocent persons! Long gone - or so they say! Nevertheless, this practice continues in many countries. Read only the UN Special Rapporteur's report on Torture submitted to the Commission on Human Rights in April 1996, to be convinced of that ${ }^{16}$

As practices of torture and cruel, inhuman, or degrading treatment occur in all parts of the world very few states are immune to the torture virus. As we know all too well from that same report, they must be publicly denounced on the basis of the many international legal instruments on human rights and fundamental freedoms that strictly forbid torture, such as - and I repeat - the Declaration on Human Rights (1948), the UN Covenant on Civil and Political Rights (1996), the Declaration (1975), and the Convention against Torture (1984). Moreover, also regional declarations and conventions to ban torture and cruel treatment from daily life have been adopted by such organizations as the Organization of American States, the Organization of African Unity, and the Council of Europe. Lawyers, physicians, and politicians, like any ordinary citizens, have a duty, either nationally or internationally to "MOBILIZE PUBLIC SHAME" on the States that do not comply with these international norms and rules.

Apart from the permanent insistence on and inspection of the scrupulous implementation of internationally agreed and applicable rules, another way of combating the evil is for the courts at all levels, to declare null and void any evidence that can be considered as obtained from the accused under pressure or worse - torture or cruel treatment. Careful research of the files of those convicted may yield information in this respect and should be reason for the court of appeal or cessation to annul the previous conviction and for lawyers to invoke such nullity. From my own experience, I know that for the police or military - whoever conducts the investigation - nothing is more discouraging than the decision of a judge to declare inadmissible, a case on the basis of unlawfully obtained evidence. Therefore, the message will be: "Torture clearly does not work!" In this context, it is equally discouraging to realize that there are judiciary systems which explicitly accept evidence obtained under pressure, for use against the accused, especially if the accused still can disclose information valuable to the prosecution.

\section{Never Should Impunity Be Granted}

A means to underline the seriousness of the policy that a government advocates to prevent torture and other cruel treatment, is to state unequivocally that whatever happens, that government will not ever grant impunity for such crimes. There should be no hope for perpetrators to get away with their crimes. Not only is this a means to discourage such behavior, it also is of the greatest importance for the healing of the wounds left by serious violations of human rights. We know that victims of torture will not be able to recover from what happened to them if they must live with the knowledge that their attackers go unprosecuted and unpunished. It is the worst possible solution to restore trust, health, and peace in a society, but - alas - not uncommon in member states of the WHO. Fortunately, the General Assembly of the UN already has recognized the need for and an obligation of the non-granting of impunity in its Declaration on the Protection of All Persons from Enforced Disappearance adopted in $1992 .{ }^{8}$

\section{Responsibility and Liability of the State}

Under international law, a State may be held responsible for the acts of its agents undertaken in their official capacity and for their omissions, even when those agents acted outside of the sphere of their authority or violate internal law. The acceptance of that responsibility brings us to the important question of the extent to which the State is under an obligation to pay compensation to the victim and/or his family whose human rights have been violated. ${ }^{9}$

I am not going to discuss in depth, the rather complex rules governing State responsibilities. Suffice it to say that the case for full redress and a fair and adequate compensation for material and immaterial damage caused by violations of human rights is in my view rather strong and convincing. Various international legal instruments, both of a declaratory and of a binding nature, provide rights for victims and relatives to be compensated by either the perpetrator or the State under whose auspices he operated. ${ }^{10}$ At a seminar in The Netherlands in 1992 on the right to restitution, compensation, and rehabilitation for victims of gross violations of human rights and fundamental freedoms, it was suggested that compensation is a form of reparation which is to be paid in cash or in kind, such as health and mental health care, employment, housing, education, and land. Even more importantly, depending on the case, may be non-monetary reparation, such as the bringing to justice of those responsible for the violations (and not grant them impunity!), the paying of tribute to the victims, strengthening the independence of the judiciary, and providing human rights training to law enforcement officers - all measures to prevent the recurrence of violations of human rights and improve the general well-being of the people. Accepting some form of "collective responsibility" for victims of human rights violations, the UN General Assembly established in the early 1980s, a Fund from which victims of torture and other cruel, inhuman, or degrading treatment and their 
families may be supported. Currently, more than 70 rehabilitation centers in over 40 countries receive grants from the UN Fund to provide health care, economic, and/or social assistance to thousands of victims. However, the number of victims still is increasing due to existing mal-practices all over the world - and so is the need for financial contributions.

\section{The Role of Physicians}

Physicians have an important role to play in the prevention of torture and in the treatment of victims. First of all, in no case shall they participate in the infliction of torture or cruel treatment and/or corporal punishment. In cases for whom they are called upon to examine persons who declare to have been tortured, and to verify their statement, the physician's role may be crucial in saving the accused from detention and prosecution, and thus, in abating malpractices. Also, and more obviously, medical doctors will play a vital role in treating and curing victims of torture. It takes special skills to assess their statements and to treat the sequelae of torture. In the first place, often very refined means of torture have been used so as to leave no physical scars. But the deeper are the wounds of the mind and the soul. To ascertain a broken arm or leg is easier than to determine that the person has undergone electric shocks. Modern torture technology is developed with an eye on medical scientific publications on the subject. In the second place, victims - or survivors as they are called by some centers - do not necessarily say they have been tortured, not seldom ashamed of what has happened to them (especially torture of women can reach intimate places) or of the fact that they were forced to give up and "confess". A physician must have special experience or get special training to find out what happened, and he must do so gently without scaring the patient who often is reminded of the past by the cell-like treatment room and the traditional white doctor's garb. It is a sad but inevitable conclusion that probably no victim of torture ever will recover completely from what he or she has suffered. In many cases, the only thing we can hope for is that the victim will be able to live with his past and play a useful role again in society.

\section{Let Us Free Man from His Burden of Fear}

I know that the WHO is committed to the health and development of man; I know that most of the governments have ratified the necessary Conventions; and I know that long before these modern instruments and laws existed, the Hippocratic Oath made unprofessional conduct both unethical and illegal. Why then does the infringement of human integrity persist in this "enlightened" age and in so many parts of the world? It behooves us all - doctors, lawyers, ministers, and individual citizens - to do our share to uphold and ensure the dignity and integrity of man and free him from the terrible burden of fear. I have been told Dr. Brock Chisholm would have agreed.

\section{References}

1. United Nations: International Covenant on Economic, Social and Cultural Rights. United Nations: New York, 16 December 1966. Article 12, paragraph 1

2. Kelman HC: The Social Context of Torture: Policy Process and Authority Structure. In: Crelinsten RD, Schmid AP (eds), The Politics of Pain :Center for the Study of Social Conflict, Leiden 1993, p 23.

3. United Nations: International Covenant on Civil and Political Rights. United Nations: New York, 16 December 1966. Article 4, paragraphs 1 and 2.

4. United Nations: General Comment no. 7: Report to the UN General Assembly, UN: Doc. A/37/40. 1982.

5. United Nations: General Assembly Resolution 37/194, Principle 2, United Nations: New York, 18 December 1982.

6. United Nations: UN: Doc. E/CN.4/1996/35+add.1 and 2. 1996

7. This phrase was coined by Professor van Asbeck, professor of international law at the University of Leyden in the 1950's.

8. United Nations: Resolution 47/133 Article 18, paragraph 1, United Nations: New York, 18 December 1992, reads: "Persons who have or are alleged to have committed offenses (acts of enforced disappearance) shall not benefit from any special amnesty law or similar measures that might have the effect of exempting them from any criminal proceedings or sanction."
9. United Nations: International Covenant on Civil and Political Rights. Article 9, paragraph 5. United Nations: New York. 16 December 1966. "Anyone who has been victim of unlawful arrest or detention shall have an enforceable right to compensation." The Human Rights Committee which monitors the implementation of the Covenant has at several occasions upheld this right to compensation and implored the defending State to provide for an adequate remedy.

10. United Nations: Convention against Torture, UNGA: Resolution 39/46, Article 14. United Nations: New York. 10 December, 1984: requires that the State Party ensure in its legal system that the victim of an act of torture obtains redress and has an enforceable right to fair and adequate compensation.

Similar obligations are contained in the following inststruments:

United Nations: Declaration: Protection of All Persons from Being Subjected to Torture and Other Cruel, Inbuman, or Degrading Treatment or Punishment. UNGA: Resolution 3452 (XXX), Article 11. United Nations: New York. 09 December, 1975.

United Nations: Declaration: Basic Principles of Justice for Victims of Crime and Abuse of Power. UNGA: Resolution 40/34. United Nations: New York. 29 November, 1985. 